University of Nebraska - Lincoln

DigitalCommons@University of Nebraska - Lincoln

USDA National Wildlife Research Center - Staff Publications
U.S. Department of Agriculture: Animal and Plant Health Inspection Service

April 1998

\title{
Trapping strategies for deterring the spread of Brown Tree Snakes from Guam
}

Richard M. Engeman

USDA-APHIS-Wildlife Services, s_r100@yahoo.com

Michael A. Linnell

USDA/APHIS/ADC

Follow this and additional works at: https://digitalcommons.unl.edu/icwdm_usdanwrc

Part of the Environmental Sciences Commons

Engeman, Richard M. and Linnell, Michael A., "Trapping strategies for deterring the spread of Brown Tree Snakes from Guam" (1998). USDA National Wildlife Research Center - Staff Publications. 633.

https://digitalcommons.unl.edu/icwdm_usdanwrc/633

This Article is brought to you for free and open access by the U.S. Department of Agriculture: Animal and Plant Health Inspection Service at DigitalCommons@University of Nebraska - Lincoln. It has been accepted for inclusion in USDA National Wildlife Research Center - Staff Publications by an authorized administrator of DigitalCommons@University of Nebraska - Lincoln. 


\title{
Trapping strategies for deterring the spread of Brown Tree Snakes from Guam
}

\author{
RICHARD M. ENGEMAN' and MICHAEL A. I.INNELL"
}

\begin{abstract}
The accidentai introduction of the Brown Tree Snake Boiga Iregularis to Guam has resulted in the extirpation of most of the isiand's native terrestrial vertebrates, has presented a health hazard to intants and children, and also has produced an economic probxem. Prevention of its dispersal through Guam's cargo traffic to other Pacific islands has become a high emvironmental priority. Trapping around ports and other cargo staging areas is central to an integrated pest management programme designed to deter dispersal of the specles. In this study, perimeter trapping of foresled plots characteristic of those found in port areas was found to be the most effective trap placement stralegy, although trap lines cut through the plot interior or placed along a single plot boundary were also effective. Snake removal potentially can be modelled using an exponential decay over time, providing the manager with a planning tool. Population recovery of Brown Tree Snakes in trapped plots was lound to be slow in the fragmented forested habitats found around ports.
\end{abstract}

Key words: Boiga irregularis. Exotic species, Pacific islands, Snake control.

\section{INTRODUCTION}

THE Brown Tree Snake Boiga irregularis on Guam is a worst-case example of the effects that an introduced predator can have on insular populations of native fauna (McCoid 1991). After the accidental introduction of the Brown Tree Snake to Guam in the 1940s, this species has extirpated nearly all of the native forest-avifauna (Savidgc 1987). The fruit bat populations on Guam, already severely impacted by hunting, have suffered additionally through Brown Tree Snakc predation (Wiles 1987). Several indigenous or endemic spccics of lizands also have become extinct or endangered (Rodda and Fritts 1992). The Brown Tree Snake has affected more than the native wildlife species on Guam. It has becomc an agricultural (Fritts and McCoid 1991) and an economic pest (Fritts et al. 1987). Furthermore, this rear-fanged colubrid snakc is mildly venomous and poses a potential health hazard to infants and young children (Fritts et al. 1990).

The problems besetting Guam by this exotic predator may impact other islands in the future, as this snake is well-adapted for successful transport to, and establishment at, other locations (Fritts 1988). Brown Tree Snakes are highly mobile, agile climbers that seek refuge during the daylight hours, and shipping containers and many types of cargo, as well as air and sea craft, offer ready daytime refugia. The very high densitics of Brown Tree Snakes on Cruam, and the position the island has as a focal point for shipments of commercial and military cargo in the Pacific, increasc the threats that Brown Tree Snakes could find their way into outbound air and sea traffic. Definitive sightings have becn made on Oahu in the state of Hawaii, Saipan, Tinian and Rota in the Commonwealth of the Northern Marianas (CNMI), Kwajalcin in the Marshall Islands, Dicgo Garcia in the Indian Ocean, Okinawa in the Ryukyu Islands, Wake Island and south Texas (McCoid et al. 1994). $\Lambda \mathrm{n}$ incipient population is speculated to exist on Saipan (McCoid at al. 1994).

Ccntral to an integrated control programme to detcr the spread of this species from Guam is its removal by trapping from areas adjacent to air and sea ports, and other cargo staging arcas. Here, we evaluate the efficacies of trapping stratcgies for reducing Brown Tree Snake populations in port area habitats and we examine Brown Tree Snake population recovery rates in areas where populations have been severely reduced through trapping.

\section{METHODS}

Trapping Strategies - Trapping stratcgy study plots were located in the Conventional Weapons Storage Area (CWSA) at Andersen Air Force Base (AAFB) on the north end of Guam. This restricted-access area is part of a large uplifted limestone plateau that is characterized by a secondary limestone forcst habitat (Fosberg 1960; Engbring and Ramsey 1984). The CWSA on AAFB has becn divided into rectangular units (blocks) by paved roads. Three blocks, each $457 \times 133 \mathrm{~m}(6.1 \mathrm{ha})$, were randomly selected as study plots from among the similar sized blocks at the north end of the CWSA with no two study plots adjacent to cach other. Each of the three study plots was randomly assigned one of three trap placement strategies: perimeter trapping, interior trapping, or a boundary trap line. An additional plot, $274 \times 133 \mathrm{~m}(3.6 \mathrm{ha}$ ), was sclected for a simultaneous application of perimeter and interior trapping, and is referred to as the combined plot. The traps used in this

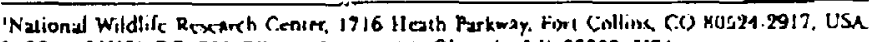
:USDNAS'HISIADC, 720 OLLaY SXreet. NW, Olympia. WA 98502, USA

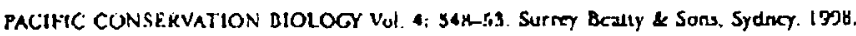


study, and the wildlife specialists that maintained them during the study, were from the USDA operational snake control programme on Guam. The operational need for these human and material resources limited their availability. Thus, only replication of the combined interior and perimeter treatments was possiblc and was carried out in the plots used for studying population recovery, described in the nexl subsection.

The $20 \mathrm{~m}$ separations between traps used operationally for snake control was applied in each plot of this study. Traps were modified crawlish traps made of $10 \mathrm{~mm}$ ( $1 / 4$ inch) wire mesh with one-way llaps installed at the entrances (e.g., Linnell $e t$ al. 1998). A live mouse protected in an interior cage served as an attractani. We defined trapping intensity from an operational standpoint as the number of traps per ha in the targeted plot. Perimeter trapping placed traps along the forest perimeter, which paralleled the roads defining the plot in an irregular (natural rather than manicured) manner. The perimeter trapping plot had 69 traps placed at the $20 \mathrm{~m}$ spacing along the forcst perimeter ( 11.3 traps/ha). The same trapping intensity (1 1.3 traps/ha in a same-sized plor) was used for the interior trapping plot where traps were placed along parallel trap lines through the forest intcrior. The lines were separated by at least $30 \mathrm{~m}$ and all traps were at least $20 \mathrm{~m}$ from the forcst edge. The boundary-trapping plot had 27 traps placed along one long edge of the forest (4.4 traps/ha). The perimeter/interior combined plot had 52 traps along the forest perimeter and another 52 traps placed along parallel interior trap lines. Again, no uraps were less than $20 \mathrm{~m}$ from the forest edge (14.4 traps/ha). Snakes captured in this plot were identified according to interior or perimeter trap location.

Traps were set on August 25, 1995, and remained in place for 40 consecutive nights. Traps were checked for snakes and the mice cared for crery 1-3 days. On August 28, 1995, 25 of the Brown Tree Snakes captured in the first three days from each plot (100 total snakes over the four plots) in the first two nights of trapping were marked with uniquely numbered microchip identification tags (MITs) (AVID, 3179 Hamner, Suite 5, Norco, CA 91760 ) and returned to the plots from which they came. The MITs were inserted through the peritoncum into the abdominal cavity, approximately 10 scalc rows anterior to the vent and on the side edge of the ventral scales. Marked snakes were $\geq 100 \mathrm{~cm}$ in length to facilitate inscrtion of MI'Ts. All subsequent captures ivere monitored for MITs. The rccapture dala on known (marked) animals formed the most reliable basis for comparing trap strategies. The time frame in which we had resources available from the operational programme was considered too short to completely trap out the snake populations in each plot (estimated around 4 months by operational trappers, see Engeman et al. 1998a).

Population Recovery - Brown Tree Snake population recovery was examincd in threc plots where populations had been severely reduced through trapping. Each plot represented a different habitat, trapping, and/or recovery time circumstances. Plot $A$ was 4.2 ha, located on Polaris Point at Naval Activities. It previously had operational trapping, coupled with an intensive trapping study simultancously using perimeter and interior trapping to remove its Brown Tree Snake population (Engeman et al. 1998a).

After traps were removed from the plot on August 4, 1995 for that study, no control work (operational or research) was conducted for eight months until the same intensive level of trapping was reimplemented for the present study on April 2, 1996 to assess population recovery. This required 214 traps equally distributed between the perimeter and interior, thus providing an additional plot for obtaining data to compare interior and perimeter trapping. The forested plots of land nearby this plot had never received snake control and the poputation available for rc-invasion was assumed to be high.

Plot B was also located at Naval Activities, near the former Sumay village site. It was 6.5 ha and also received intensive perimeter and interior trapping to remove its Brown Tree Snake population (Engeman et al. 1998a). That effort was completed on September 7 , 1995. Unlike plot A, control efforts continued in plot B after completion of population removal, as a boundary trap line on the side of the plot adjacent to naval wharf areas remained in place. The other side of the plot remained unprotected and open to re-invasion from land that had never received control. Intensive trapping was reimplemented on August 9, 1996, 11 months after the end of the first intensive trapping session. Including the boundary trap line, 260 traps were used in this plot, again equally distributed between perimeter and interior traps to provide another combined treatment plot for comparing those trap strategies.

Plot $C$ was the combined perimeter and interior trapping plot already used to study trapping strategies in the CWSA at AAFB. This plot was subjected to less human detivity than plots $A$ and $B$ al Naval Acrivities because it was in a restricted area. Nlso, it was located at the edgc of the CWSA, near to contigunus 
jungle that had never received snake control. this plot rercived the most intensive trapping of the plots used to study trap placement siratcgics (160 snakes were removed from this plot). However, captures ncver reached zero for an extended period of time, unlike the other two plots we uscd for examining pupulation recuvely. In those two plots, captures had prcviously reached zero for over four wecks (Engeman et al. 1998a). After trapping was completed for comparing trap placement strategies on October 2, 1995, no snake control was conducted near the plot for 6.5 months. Trapping was reimplemiented on April 12, 1996 to evaluate its population recovery. The same placement of 52 traps each on the perimeter and interior was repeated.

Data Anatyses - Product-limit life tables (Kaplan and Meier 1958) were calculated to examine recapture rates of MTT-marked snakes within the trapping strategy plots with perimeter, interior and boundary trap placements. Wilcoxon comparisons of survival curves (Kalbfleish and Prentice 1980) were applied to comparc recapture rates over time among the three placement strategies. Capture-recapture cstimates using programme NOREMARK (White 1996) were used to index the initial population levels in each plot. Exponential regression was used to describe snake removal (new captures only) in each trapping stralegy ploc. Perimeter and interior trapping were compared using chi-square goodness of fit tests for all plots where data were collected on both methods. When sample sizes were too small in validly apply chi-squarc methods, exact binomial probabilities were calculated to test whether the proportion of captures were the same for perimeter and interior traps.

\section{RESURTS}

Trapping Strategies - Of the 25 MIT marked snakes releascd in each plot, 14, 16 and 12 were recaptured (Table 1), respectively, in 37 nights of trapping (post-releasc) in the perimeter, interior, and boundary trapped plots. Confidence intervals for mark-recapture estimates of initial populations in cach plot exhibited considerable overlap (lable 1). It is probably best to consider these similar estimates as indices of initial populations, because population closure was not assured, although considerable Brown Tree Snake site fidelity in the C.WSA are has been demonstrated using radiotelemetry (Tobin et al. in press). No ovcrall differences in recapture rates $\left(x^{2}=1.299\right.$. $\mathrm{d} \Gamma=2, \mathrm{p}=0.52$ ) werc indicated nor were differences detected among recapture curves (Wilcoxon comparison of Kaplan-Meier survival curves $x^{2}=3.12, \mathrm{df}=2, \mathrm{p}=0.21$ ).
Table 1. Weckly murribers of recaplutis at 25 marked Rrnwn 'tree Snakes and sumanary saristics for three. 6.1 ha plots with applications of difTerert (mapping stracegics.

\begin{tabular}{cccc}
\hline & \multicolumn{3}{c}{ Trap Stratcgy } \\
Weck & Perimeter & interior & Boundary \\
\hline 1 & 10 & 8 & 9 \\
2 & 4 & 5 & 5 \\
3 & 0 & 1 & 2 \\
1 & 0 & 2 & 2 \\
\hline Total & 14 & 16 & 12 \\
Initial population & 195 & 176 & 171 \\
estimatc & & & \\
95\% confidence limit & $159-273$ & $151-221$ & $110-857$ \\
Derisity estimatc & 32.0 & 28.9 & 28.0 \\
(snakes/ha) & & & \\
Total srsikes caprured & 208 & 178 & 87 \\
\hline
\end{tabular}

In contrast to the results for individually applied treatmenis, strong differences werc derected in the combined plot where the same population was subjected to both interior and perimeter trapping (Table 2). Perimeter traps captured 119 snakes versus only 41 for the interior traps $\left(x^{2}=19.01, d f=1, p<0.0001\right)$. Reraptures demonstrated a similar ratio with 10 snakes captured on the perimeter and three on the interior (hinomial probability $=0.046$ ).

Table 2. Weekly numbers of recaptures of 25 marked Brown Tree Snakes and numbers of new captures between perimeter and incerior traps in a 3.6 ha plot with both trapping scratcgics.

\begin{tabular}{lrrrrrr}
\hline & \multicolumn{3}{c}{ New Captures } & \multicolumn{3}{c}{ Recaptures } \\
Week & Perimeter & Interior Sum & \multicolumn{1}{c}{ Perimeter Interior Sum } \\
\hline 1 & 65 & 30 & 96 & & & \\
2 & 14 & 5 & 19 & 8 & 2 & 10 \\
3 & 17 & 3 & 20 & 1 & 1 & 2 \\
4 & 10 & 2 & 12 & 1 & 0 & 1 \\
5 & 12 & 1 & 13 & 0 & 0 & 0 \\
Total & 119 & 41 & 160 & 10 & 8 & 13 \\
\hline
\end{tabular}

Weekly snakc removal was well described for each plot by an exponential decay regression equation of the form:

$$
y=a e^{b x} \text {, }
$$

where $y$ represents the wcekly number of captures and $x$ represents the number of weeks of trapping. The $\mathrm{R}^{2}$ values for the exponential regression cquations from the perimeter, interior, boundary and combined plots were, respectively, $0.91,0.85,0.97$ and 0.78 .

Population Recouery - Trapping on Plot A was discontinued after 7.5 weeks on May 24, 1996. During that time 25 Brown Trece Snakes were captured, 21 in perimetcr traps and four in interior traps $\left(x^{\psi}=5.78, d f=1, p=0.0162\right)$. Plot $B$ trapping continued for five weeks until September, 12, 1996, resulting in 17 Brown Tree Snake captures. Of these, 13 were captured 
in perimeter traps and four in interior traps (binomial probability $=0.025$ ), all from or near the opposite side of the plot where the boundary irap line had remained in place. Trapping on plot $C$ covered seven weeks, ending on May 31, 1996. A total of 74 snakes was captured, but perimeter and interior captures inadvertently were not distinguished during data recording.

\section{DISCUSSION}

In contrast to the individual plot results, perimeter trapping in the combined plot exhibiled about three times the capture rate as did interior trapping, for both marked snakes and new captures. Similar results were seen in the plots used to investigate population recovery, where perimeter traps accounted for 3 to 5 times the captures as interior traps. Indications that perimetcr trapping could effectively remove Brown Tree Snake populations from forested plots have been noted from operational capture reconds, and formed a basis to speculate that when these snakes encounter the forest edge, they tend to stay along the forest perincler, thus producing a higher probability of encountering a trap on the perimeter than on the interior Engeman et al. (1998b). The greater caprure rates of unmarked snakes for perimeter traps also likcly was due to their position for intercepting invading snakes. However, the consistent elevated capture rates for snakes in perimeter traps versus interior traps in the same plot, plus a similar catch ratio for marked snakes within a plot strongly supports the notion that perimeter trapping is more effective than interior trapping for plots in the size range of this study. Explanations for why differences were not found betwecn recapture rates in the perimetertrapping-only and the interior-trapping-only plots might begin by noting that the oxtcriormost traps of the interior trap lines perhaps were close enough $(20 \mathrm{~m})$ to the perimeter to have similar elficacy as traps on a perimeler trap line. Similarly, the boundary-trapping plot may have produced comparable results to the ather two strategies because the plot may have been narrow enough to bring the snakes into contact with the one side of the plot with traps. Further investigation using different-sized (larger) plots and larger cohorts of snakes, if possible, within each plot might clarify thesc results.

As plot dimcnsions increase, boundary trapping on only a portion of the perimeter could not be expecicd to remove snake populations as effectively as the other two placcinent strategics that more completely encompass the plot. This tendency scems to be hinted in the total capture data (lable 1), albeit not statistically cstablished. Also, as plot dimensions increase, the likelihood diminishes that perimeter trapping would effectively capture the snakes in the central-most portion of the plot. Fortunatcly, plots of forested habital in ports and orher cargo staging areas tend to be of similar dimensions to the plots used in this study, allowing a choice of trapping strategies. Further study is recommended to investigate the relative efficacics of the trap placement strategies as plot dimensions are increased, as this could greatly affect the practical application of snake control resources.

Depending on circumstances, population recovery rates appear to be relatively slow. Plots $A$ and $B$ esscntially had their populations removed through operational control efforts and a previous intensive trapping study (Engeman et al. 1998a). Here, plots $A$ and $B$, respectively, produced only 25 ( 6.0 snakes/ha) and 17 (2.6 snakcs/ha) captures 8 and 11 months later in these succeeding intensive trapping efforts. The respertive recovery rates for plots $A$ and $B$ were 0.75 and 0.24 snakes/ha/mo. Plot $C$, although not initially "trapped out," produced 74 captures (20.6 snakes/ha), as compared to 160 snakes $(44.4$ snakes/ha) in the trap placement phase of the study 6.5 months earlier.Thus, the maximal (if all snakes actually had been removed) "recovery rate" was $\leq 3.2$ snakes/ha/mo.

One characteristic of all three population recovery plots was a well-defined perimeter where roads or lawns scparated them from the nearest adjaccnt forested areas. Recovery rates for plots in direct contact with adjacent forested areas not having received snake control would be expected to be greater. However, insight can be gained from considering the differences among the population recovery plots. Plot $C$ most likely had a viable snake population at the beginning of the recovery period. Bcyond that, this plot was in a corner of a restricted area on AAFB adjacent to conliguous forest and, hence, represented a habitat with less human activity than the areas around plots $A$ and $B$. This by itself would seem to promote a much more rapid population recovery rate from a trapping programme. Naval $\Lambda$ ctivities, where plots $\Lambda$ and $B$ wcrc located, is an area of patchy forested habitat with fewer population reservoirs and optimal habital curridors through which trapped arcas could be reinvaded and repopulated. The boundary trap line on the wharf side of plot B also would act as a population sink that wesuld further reduce the. rate of population recosery.

The plot sizes used in the present study atc typical of the forcsted labilats fragmented by 
development in the arcas around air and sca ports, industrial and ocher cargo staging arcas on Cuam. The results from both the trap placement study plots and the population recovery plots have important management implications. First, perimeter trapping, which is a less labor-intensive method to implement and maintain in the field because it does not require cutting and traveling trap line trails through the lorest, also was the most ellective trap placement strategy for plots of this size. Thus, perimeter trapping would allow control personnel to potentially apply more traps, cover greater areas, and more readily provide high quality care of the traps. Second, popu. lation recovery in fragmented habitat areas occurred slowly, especially when a boundary trap line was left on one side of the plot. Once populations have been reduced or removed, maintaining some strategically placed traps around the plot should limit population recovery. Using a careful sequence for targeting plots of forest habitat for control, the habitat surrounding most areas on Guam at high risk for contributing to snake export could be effectivcly trapped to substantially reduce snake populations. Based on our findings, it is reasonable to assume that plots in developed areas where most of Guam's cargo is handled could have Brown Tree Snake populations efficiently reduced to very low densities and subsequently maintained that way by leaving a small number of traps in the plots.

Although daca from more plots will be required for verification, the exponential model fitcing results imply that after trapping has been initiated in a plot, managers might be able to estimate remaining population levels or predict the time needed to reduce the plot population to a certain level. A practical implementation of a predictive model would require similar analyses for a number of plots to verify that the same functional form (exponential decay) provided an adequate fit to those data, and that the resulting exponential decay models could be combined into a general random cocfficients model (Laird and Ware 1982; Littell et al. 1996) to describe snake removal from a gcneric plot.

The information presented here helps managers optimice resources for snake removal and minimize of population recovery in the habitats typically adjacent to sitcs where Brown Tree Snakes could invade cargo or cratt departing Guam. The samc information could also have application to endangered species restoration on Guam where snake population removal may be needed around nesting trees or other sites, or may be nceded to prepare plots for reintroduction of birds from capivebred populations.

\section{ACKNOWLEDCEMENTS}

R. Bruggers, M. Fall, E. Campbell, P. Savarie and (;. Rudda provided helpful reviews of this manuscript. Three anonymous reviewers provided very useful suggestions. This rescarch was condurted under funding provided to the US Department of Agriculture/Animal and Plant Hcalth Inspection Service/Animal Damage Control Operations/Washington State Director's Office by the US Dcpartment of Derense under DOD MIPR-061-95, "Operalional Control of Brown Tree Snakes in Guam."

\section{REFERENCES}

Engbring, J. and Ramsey, F. L., 1984. Distribution and abundance of the forest birds of Guam: results of a 1981 survey. U.S. Fish and Wildlife Service FWSJOBS. 84/20. $54 \mathrm{Pp}$.

Engeman. R. M., Linnoll, M. A, Pochop, P. A and Gamboa, J., 1998a. Substantial reductions of Brown Tree Snake (Boiga irregularis) populations in blocks of land on Cuam through operational trapping. Internat. Biodegro. Biodstoriora. (in press).

Engeman. R. M., Sayama, S. and Linnell, M. A., 1998b. Operational utility of perimeter trapping for removing brown tree snakes (Boigo irregularis) from a delined area. The Snceke (in piess).

Fosbers. F. R.. 1960. The vegetation of Micronesia. Bull. Amer. Mus. Nat. Ilist. 119: 1-75.

Fritts, T. H., 1888. The brown trec snake, Boigo irregularis, a threat to Pacific islands. Biological Report 88(31), U.S. Deparment of Interior. Fish and Wildlife Service, Washington, DC. 20240. $86 \mathrm{Pp}$.

Frits, T. H. and McCoid, M. J.s 1991. Predation by the brown tree suake (Boign itregularis) on poultry and other domesticated animals on Guam. The Srake 23: $75-80$.

Frius, T. H., McCoid, M. J. and Haddock, R, L., 1990. Risks tu infants on Guam from bites of the brown trce snake (Boign irregularis). Amex J. Trop. Med. Hyg. 42: $607-11$

Fritts, T. H., Scott, N. J. and Savidge, J. A., 1987. Aativity of the arboreal brown tree snake (Boiga irregalaris) on Cuam as deremined by electrical ourages. Snathe 19: $51-58$.

Kalbneish, J. D. and Prenrice, K. L., 1980. The Statistical Analysis of Failure Time Data. John Wiley and Sons, New York, 3218 .

Kaplan, E. L. and Meier, P,, 1958. Nonparametric estimation from incomplete ubservations. J. Amer. Stat. Assoc. 53: 157-81.

Laird. N. M and Ware J. H., 1982. Randon-effects models for longitudinal data. Biometrics 38: 963-74.

Linnell. M. A., Engeman, R. M., Pirzler, M. E., Watten. M. O., Whichead. C. F and Miller, R. (:, 1998 An evaluation of two designis of stamped necal rap flaps for use in the operational control of brown trec snakes (borga itregularis). The Snake (in press).

Litlell, R. C., Milliken, C. A., Stroup, W. W. and Wolfinger, R. D., 1996. SAS Systcm for Mixed Models. SAS Instilute. Cary, NC. 65S Pp. 
McCoid, M. J., 1991. Brown tree snake (Boigo irregularis) on Cuam: a worst case scenario of an introduced predator. Micronesia 3: 63-69.

MCCoid, M. J., Fritts, T. H. and Campbell, E. W., 1994. A brown tree snake (Cakubridae: Boiga irregularis) sigheing in 'iexas. Nex. J. Sci. 45: 365-08.

Kodda, C. H. and tirits, T: H., 1992. The impact of the Inuroduction of the colubrid suake Boigu irregularis on Cuam's lizards. J. Herpetol. 26: 166-74.

Savidge, J. A, 1987. Extinction of an island forest avifauna by an introduced snake. Ecology 68: 660-68.
Tobin, M. E., Sugihara, K. T.. Puchop, P. A. and Linnell, M. A. 1998. Nightly and scasonal movements of brown tree snakes un Guam. J. Herpetol. (in piess).

White. C. C.. 1996. NORF.MARK: population cstimation from mark-resighting surveys. Wildl. Soc. Bul. 24: 50-5y.

wiles, C. J., 1987. The status of Guit bats on Guam. Ptec. Si. $41: 148-57$. 